\title{
PDAM WATER QUALITY EVALUATION OF PHYSICAL, CHEMICAL, AND BIOLOGICAL PARAMETERS IN MANJANGLOE VILLAGE, TAMALATEA SUB-DISTRICT, JENEPONTO DISTRICT
}

\author{
Fitriani Kahar ${ }^{\mathrm{a} *}$ \\ a Department of Health Analyst ; Poltekkes Kemenkes Semarang \\ Wolter Monginsidi 115 ; Pedurungan ; Semarang 50192 ; Indonesia
}

\begin{abstract}
Water is the most important human need. The problem that arises in the Jeneponto district is the PDAM water that is used daily by the community is turbid, smelly, and often causing an itchy effect on the skin. This research is a type of observational study with a descriptive approach and laboratory test because the aim is to describe or describe the state of water quality of PDAM in terms of physical parameters, chemical parameters, and biological parameters in Kelurahan Manjangloe Kecamatan Tamalatea Kabupaten Jeneponto. The population and sample in this study is clean water from all PDAM taps received by the community in Manjangloe village Tamalatea Sub-district Jeneponto District. The results obtained from the physical parameters, there are 10 samples $(100 \%)$ that meet the requirements, while the biological parameters there are 6 samples $(60 \%)$ that meet requirements, while for chemical parameters there were $7 \mathrm{pH}(70 \%)$ qualified parameters for checking water, while for the remaining chlorine water inspection parameters it was found that 0 samples $(0 \%)$ were eligible. Suggestions the local PDAM should continue to maintain, improve, and monitor the quality of clean water both in the outlet pipe and the water that is distributed to customers.
\end{abstract}

Keywords: water quality ; PDAM ; physical parameters ; chemistry ; biology

\section{Introduction}

Water is a special substance, water appears in the form as well as liquid, solid (ice, glaciers) and gas (steam) water in three spaces: on the surface of the earth, in the earth and the earth's atmosphere. On the surface of the earth, water is in the form of oceans, ice fields or snow, rivers, and funds.

The specific target in this study is to prove and assess the quality of PDAM water in Kelurahan Manjangloe Kecamatan Tamalatea Kabupaten Jeneponto. The study was conducted at the PDAM in Manjangloe Village Tamalatea Sub-district Jeneponto District.

The research will be carried out in 2019 . This research uses descriptive analysis and then compared with the water quality standards set by the Minister of Health Regulation No. 416 / Menkes/Per/IX/1990 to find out how the

*) Corresponding Author (Fitriani Kahar)

E-mail: fitrianikahar555@gmail.com quality is, so conclusions and suggestions are obtained.

The object of research is PDAM water. The sample in this study was clean water from the PDAM that was received by the people of the village of Manjangloe Tamalatea Sub-district, Jeneponto District. The research process was carried out for 3 months starting at the site survey stage until the water quality inspection in the laboratory. Data analyzed descriptively presented in tabular form accompanied by narration.

\section{Method}

This research uses descriptive analysis and then compared with the water quality standards set by the Minister of Health Regulation No. 416/Menkes/Per/IX/1990 to find out how the quality is, so conclusions and suggestions are obtained. 


\section{Result and Discussion}

This research was carried out in PDAM Manjangloe Village Tamalatea Sub-district Jeneponto District. Sampling was carried out at
10 points according to a predetermined locus. The results of our research are as follows;

Table 1. PDAM Water Quality Evaluation Of Physical, Chemical And Biological Parameters In Manjangloe Village, Tamalatea Sub-District, Jeneponto District

\begin{tabular}{|c|c|c|c|c|c|c|c|c|}
\hline \multirow{2}{*}{$\begin{array}{l}\text { Sampling } \\
\text { Point }\end{array}$} & \multicolumn{2}{|c|}{$\begin{array}{c}\text { Water Physical } \\
\text { Examination }\end{array}$} & \multicolumn{2}{|c|}{ Water Biological Examination } & \multicolumn{4}{|c|}{ Water Chemical Examination } \\
\hline & Turbidity & Information & Coliform Total & Information & Chlor & Information & $\mathrm{pH}$ & Information \\
\hline $\mathrm{A}$ & 1.34 & qualify & 1.600 & Not equal & 0 & Not equal & 7.2 & qualify \\
\hline B & 1.15 & qualify & 7.8 & qual & 0 & Not equal & 6.9 & qualify \\
\hline $\mathrm{C}$ & 0.64 & qualify & 13 & Not equal & 0 & Not equal & 7.38 & qualify \\
\hline $\mathrm{D}$ & 0.80 & qualify & 2 & qual & 0 & Not equal & 6.95 & qualify \\
\hline $\mathrm{E}$ & 0.45 & qualify & 4.0 & qual & 0 & Not equal & 6.39 & Not equal \\
\hline $\mathrm{F}$ & 0.79 & qualify & 4.5 & qual & 0 & Not equal & 6.34 & Not equal \\
\hline G & 0.74 & qualify & 0 & qual & 0 & Not equal & 6.44 & Not equal \\
\hline $\mathrm{H}$ & 5.31 & qualify & 350 & Not equal & 0 & Not equal & 7.07 & qualify \\
\hline $\mathrm{I}$ & 1.40 & qualify & 540 & Not equal & 0 & Not equal & 6.91 & qualify \\
\hline $\mathrm{J}$ & 0.91 & qualify & 0 & qual & 0 & Not equal & 7.26 & qualify \\
\hline
\end{tabular}

This table shows the results of water quality inspection of PDAM physical, chemical and biological parameters in Kelurahan Manjangloe Kecamatan Tamalatea district. Jeneponto. The results of the measurement of clean water are compared with the quality standards for clean water set by the Ministry of Health No. 416/ Menkes/Per/IX/1990. From these measurements, the results are obtained.

\section{Coliform Total}

The table above shows that all sampling points contain total Coliform which is between $0-1.600 / 100 \mathrm{ml}$ water sample, thus the results do not meet the specified clean water quality requirements ie for clean water from standard piping maximum is $10 / 100 \mathrm{ml}$ of water sample. 4 points do not meet the requirements, namely at points A: $1.600, \mathrm{C}: 13$, point $\mathrm{H}: 350$, and point $\mathrm{I}$ : 540.

Coliform stool is a normal inhabitant of the digestive tract of humans and animals, can survive in the human intestine. This type of coliform is used as an indicator in determining the quality of drinking water. If the discovery of these bacteria in water and if taken by bacteria that are still alive enter the intestine and develop can cause disease. From the results of laboratory tests show that the total coliform content of all sample points, 4 points do not meet the requirements. This is certainly influenced by the results of the remaining Chlor measurements which show that all sample points also did not have any remaining Chlor which functions to kill pathogenic bacteria. As long as the remaining chlorine is present there is no coliform in the water as long as there is no pollution in the distribution path in the form of leakage in the piping. Besides, it is also influenced by the habit of a small portion of the community disposing of feces in canals/canals which are the source of raw water from the PDAM.

\section{Remaining Chlor}

The table above shows that the entire sample did not have residual chlorine, which means it did not meet the requirements of the Republic of Indonesia Health Regulation No. 416/Menkes/Per/IX/1990 i.e. there must be remaining chlorine $0.1 \mathrm{mg} / \mathrm{L}$ and a maximum of $0.3 \mathrm{mg} / \mathrm{L}$ water sample as a disinfectant. Thus these results do not meet the requirements for clean water quality determined by the Minister of Health RI No. 416/Menkes/Per/IX/1990.

In theory, chlorine derived from CL2CaCOCL2 (Lime) chlorine or HOCL (Hypochloric Acid) solution will oxidize all oxidizable substances including ammonia can be removed as N2 gas, it is feared that BreakPoint Chlorination (Neutral Chlorination) given at the beginning of the processing is not in accordance with the needs of Chlor so that there is no remaining active Chlor to kill germs that will enter.

The remaining chlorine contained in clean water depends on the proper administration of chlorine, in clean water there must be a residual chlorine of $0.1 \mathrm{mg} / \mathrm{L}$ and a maximum of 0.3 $\mathrm{mg} / \mathrm{L}$. As long as the remaining Chlor is still present in the water then there is no coliform if 
the pipes do not leak, the results of the study found no residual Chlorine while the standard set must be a residual Chlor $0.1 \mathrm{mg} / \mathrm{L}$ and a maximum of $0.3 \mathrm{mg} / \mathrm{L}$ this is because the chlorination process used in the chlorine processing does not meet the needs of Chlor so that at all points there is no residual active Chlor for eradication of pathogenic germs, if there is no residual Chlor then the possibility of distributed water will be contaminated by pathogenic bacteria therefore clean water before distribution needs to be sufficient disinfectant to prevent contamination during the journey to the consumer (user).

\section{Turbidity}

The table above shows the level of turbidity of PDAM water in Kelurahan Manjangloe is between 0,45-5,31 NTU. Whereas the clean water quality standard based on turbidity parameters according to Permenkes RI No. 416/Menkes/ Per/IX/1990 are 25 NTU.

This means it has met the requirements for clean water quality according to Permenkes RI No. 416/Menkes/Per/IX/1990.

There was a slight increase in turbidity at point $\mathrm{H}$ (intake raw water) due to the fact that the settlement was rather dense so that the activity of the population around the canal also increased which directly or indirectly affected the quality of raw water, in addition it was supported by an increase in flow velocity so that the cliffs impermanently drained canals accompanied by erosion of canals/canals and the entry of contamination from agricultural waste due to impermanent canals/canals, this affects the degree of turbidity. Whereas the decrease in turbidity level at other points is caused by the slowing of the flow velocity at the PDAM intake to allow solid sediments to settle by gravity and the process of chlorination or mixing of chlorine at that point. In theory, the precipitation depends on several factors including flow velocity, the turbidity of the liquid, specific gravity of the liquid, grain diameter and specific gravity of the granules. Whereas at another point it has decreased with the same average turbidity rate of 0.5 NTU due to having gone through a chlorination process so that the turbidity level has decreased.

\section{pH (Degree of Acidity)}

In the above, it can be seen that the $\mathrm{pH}$ of PDAM water in Kelurahan Manjangloe
Kecamatan Tamalatea Kabupaten Jeneponto ranges from 6.34-7.26. Whereas the clean water quality standard of the $\mathrm{pH}$ parameters according to the Republic of Indonesia Health Minister Regulation No. 416/Menkes/Per/IX/1990 is pH 6.5 to 9.0. Thus these results do not meet the specified clean water quality requirements. 3 points do not meet the requirements, namely at point E: 6.39, point F: 6.34, and point G: 6.44 .

Water is a very good solvent, so it is assisted with an abnormal $\mathrm{pH}$ that can dissolve various chemical elements in its path. Drinking water should be neutral non-acidic and not alkaline to prevent heavy metal dissolution and tissue corrosion. If the $\mathrm{pH}$ is less than 6.5 it will cause an unpleasant taste, corrosion of the drinking water distribution network, dissolution of heavy metals and become a poison that is harmful to health while a $\mathrm{pH}$ of more than 9.0 can interfere with digestion.

The $\mathrm{pH}$ of water naturally ranges from 4-9 theoretically to $\mathrm{pH}$ from $0-14$ where $\mathrm{pH}=0$ is called very acidic and $\mathrm{pH}=14$ is called very alkaline, whereas $\mathrm{pH}=7$ indicates neutral at $25^{\circ} \mathrm{C}$. Abnormal pHs of water can be caused by the introduction of acids or bases, a pH smaller than 6.5 turns into poison and a $\mathrm{pH}$ greater than 9.0 can cause chemical compounds that turn into poisons that interfere with health.

\section{Conclusion and Suggestion}

Based on the measurement results of several air quality parameters to clean water from PDAM in Kelurahan Manjangloe with agreement on clean air quality according to Permenkes RI No. 416/Menkes/Per/IX/1990 then the following conclusions can be drawn:

The results above show that PDAM water quality based on biological parameters (total coliform examination) contained 6 samples $(60 \%)$ that met the requirements and 4 samples $(40 \%)$ that did not meet the requirements, and based on physical parameters (turbidity) contained 10 samples $(100 \%)$ that met the requirements and 0 samples $(0 \%)$ that did not meet the requirements, and based on chemical parameters $(\mathrm{pH}$ and residual chlorine), for the water $\mathrm{pH}$ inspection parameters showed that there were 7 samples $(70 \%)$ that met the requirements and 3 samples $(30 \%)$ did not meet the requirements while for the remaining chlorine water inspection parameters showed that 0 samples $(0 \%)$ were eligible and the overall sample for 10 samples $(100 \%)$ did not meet the requirements. 
Local PDAMs must put Chlorin by the amount of Chlor determined because there needs to be Chlor residue to kill the bacteriology flowing in the piping system. We recommend that the local PDAMs continue to maintain, improve and monitor the quality of clean PDAM water both in the outlet pipe and the water that is distributed to customers. Local PDAMs should provide water inspection laboratories and draw maps of water distribution.

\section{Acknowledgements}

Thank you to the Ministry of Research and Technology of the Republic of Indonesia for funding this research, to the Pancasakti University, which has made many contributions to this research, and to the PDAM in the Regency of Jenepont, who have assisted the research process to completion.

\section{References}

Ermalena. 2017. Indikator Kesehatan SDGs Di Indonesia. Jakarta : artikel.

Sastrawijaya A.Tresna. 2009. Pencemaran Lingkungan. Jakarta : Rineka Cipta.

Tri Angga. 2003. Diare, Derita Rakyat Kekurangan Air Bersih, (Online), (http \\www.tribuntimnur.com / 28 Februari 2018).

Lebih Dari 40 Persen Air Minum Tercemar Bakteri E.Coli. 2016. (Online), (http\\www.kompas.com Diakses 10 Februari 2018).

Dirjen Penyehatan Lingkungan dan Permukiman. 2011. PAMSIMAS (Penyediaan Air Minum dan Sanitasi Berbasisis Masyarakat ). Jakarta : Kemenkes RI.

Profil Dinas Kesehatan Kabupaten Jeneponto tahun 2017.

Ronny. 2016. Strategi Penyuluhan Air Bersih Terhadap Peningkatan Pengetahuan Dan Sikap Masyarakat Dalam Upaya Kesehatan Lingkungan Di Kota Makassar. Disertasi. Makassar : PKLH UNM.

Kahar Fitriani. 2014. Hitung Most Probable Number (MPN) Escherichia coli Pada Air
Manisan Mangga Yang Dikonsumsi di Sekitar kampus Universitas Indonesia Timur . Makassar: Jurnal Kesehatan STIK Tamalatea.

Latif Iin Wahyuni. 2012. Studi Kualitas Air Minum Isi Ulang ditinjau Dari Proses Ozonisasi, Ultraviolet, Dan Reserved Osmosis Di Kecamatan Kota Tengah Dan Kecamatan Kota Selatan Gorontalo. Jurnal Kesehatan.

Notoatmojo, Sukijo, 2009, Promosi Kesehatan Global. Jakarta, Rhineka Cipta.

Peraturan Menteri Kesehatan RI No.492. 2010. Tentang syarat-syarat Kualitas Air Minum. Jakarta : kemenkes RI.

Undang-Undang RI No 32. 2009. Tentang Pengelolaan Lingkungan Hidup. Jakarta: Kementrian Kesehatan RI.

Peraturan Menteri Kesehatan RI No.416. 1990. Tentang syarat-syarat Kualitas Air Bersih. Jakarta : kemenkes RI LB.

Thompshon, Bartram. 2003. Provide Clean Water, Keeping Water Clean In Intergrated Approach.

Marwati. 2008. Politeknik Kesehatan Denpasar Jurusan Kesehatan Lingkungan Program Megister Ilmu Lingkungan Program Pascasarjana Unud.

Harris AR, Davis J, Boeht AB. 2003. Mechanism of post-supply contamination of drinking water in Bagamoyo. Tanzania. Journal of Water and Health. 11:543-54.

Josephine A, Morello Paul A, Granato Helen Eckel Mizer. 2003. Laboratory manual and workbook in microbiology applications to patient care. Edisi ke7. New York: Mc Graw-Hill.

Slamet, Juli Soemirat. 20011. Kesehatan Lingkungan. Yogyakarta: Gadjah Mada University Press.

Djaffar. 2000. Penyediaan Air Bersih (PAB). Makassar : Jurusan Kesehatan Lingkungan, FKM Unhas.

Peraturan Menteri Kesehatan Republik Indonesia No.907. 2002. Tentang Syarat-Syarat Dan Pengawasan Air Minum. Jakarta : Kemenkes RI. 